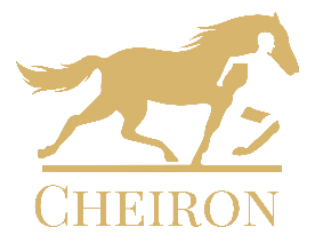

Cheiron: The International Journal of Equine and Equestrian History

Vol. 1, Issue 1/2021

(C) The Authors 2021

Available online at

http://trivent-publishing.eu/

\title{
Riding for Health and Pleasure: \\ A Brief Historical Overview \\ with Reference to Latvia in the Baltic Region
}

Anastasija Ropa, Ludmila Malahova

\begin{abstract}
Throughout premodern history, horses were used primarily for labour and transportation, as well as in the military sphere. With the advent of motorized vehicles and other means of transport, the emphasis shifted to using horses in sport as well as for leisure. This article begins by examining briefly the few pre-modern European sources that mention riding as health-promoting and pleasurable activity, continues with a discussion of the more numerous and detailed references to the benefits of riding in the eighteenth and nineteenth-century sources and concludes with an overview of the rise of riding therapy and recreational riding in Germany and the Baltics in the twentieth century.
\end{abstract}

\section{Keywords}

Riding therapy; recreational riding; equestrian tourism; equine therapy; leisure riding.

DOI: 10.22618/TP.Cheiron.20211.1.233010

CHEIRON is published by Trivent Publishing

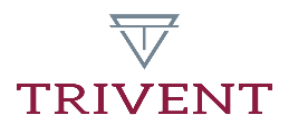

This is an Open Access article distributed in accordance with the Creative Commons Attribution Non Commercial (CCBY-NC-ND 4.0) license, which permits others to copy or share the article, provided original work is properly cited and that this is not done for commercial purposes. Users may not remix, transform, or build upon the material and may not distribute the modified material (bttp:/ / creativecommons.org/licenses/by-nc/4.0/) 


\title{
Riding for Health and Pleasure: A Brief Historical Overview with Reference to Latvia in the Baltic Region
}

\author{
Anastasija Ropa, ${ }^{1}$ Ludmila Malahova ${ }^{2}$
}

\begin{abstract}
Throughout premodern history, horses were used primarily for labour and transportation, as well as in the military sphere. With the advent of motorized vehicles and other means of transport, the emphasis shifted to using horses in sport as well as for leisure. This article begins by examining briefly the few pre-modern European sources that mention riding as health-promoting and pleasurable activity, continues with a discussion of the more numerous and detailed references to the benefits of riding in the eighteenth and nineteenth-century sources and concludes with an overview of the rise of riding therapy and recreational riding in Germany and the Baltics in the twentieth century.
\end{abstract}

\section{Keywords}

Riding therapy; recreational riding; equestrian tourism; equine therapy; leisure riding

\section{Introduction. Horses for courses throughout history}

For a long time, equestrian sports were dominated by the military, whereas leisure riding was the recourse of the high and middle classes, though the implications were different: for the elites, horses were an integral part of their status, and horsemanship was one of the social accomplishments. For the non-noble but wealthy people, riding was a means of showing one's affiliation to a certain set of cultural values, but also a means of enhancing one's health. In literature, we find references to the benefits of riding for health and to recreational riding from the eighteenth century onwards. Today, the horse is less a status symbol than a companion, with people from a variety of classes and incomes being able to afford keeping a horse or a pony or at least taking riding lessons or an occasional recreational ride.

\section{Horse riding for health and for pleasure from Xenophon to Dom Duarte}

One of the earliest surviving treatises, and certainly the best known of the ancient equestrian

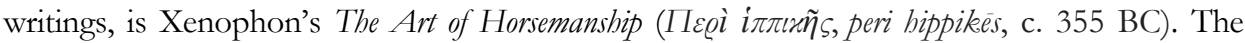
treatise is meant as a manual for cavalry riders, as Xenophon states explicitly at the beginning of chapter 2: "It does not seem necessary for me to describe the method of breaking a colt, because those who are enlisted in the cavalry in our states are persons of very considerable means, and take no small part in the government."'3 Xenophon, thus, writes for the military elites, and later

\footnotetext{
${ }^{1}$ Department of Management and Communication Science, Latvia.

2 Department of Management and Communication Science, Latvia.

${ }^{3}$ Xenophon, Horsemanship, trans. Morris H. Morgan (Boston: Little, Brown, and Company, 1893), 20.
} 
on he describes the preparation of a horse for parades, battle movements and hunting. However, Xenophon does mention the need for a young man "to see that his own condition and that of his horse is good, or, if he knows this already, to keep up his practice in riding." "For Xenophon, thus, riding is both necessary for civil and military service, but also the means of taking care of one's health. Both aims are closely related, and it would be artificial to try to draw a borderline between the two.

Throughout the medieval period, the treatises written in Europe tended to concentrate on hippiatric matters, including the care and training of horses, rather than on the training for riders or the benefits of horse riding. Indeed, riding was primarily undertaken with a practical purpose in mind: either for transportation or for military purposes. Even hunting, especially hunting big game, was seen not only as recreation but also as preparation for warfare. This point is stressed already by Xenophon, who writes: "The rider must have a firm seat when going at full speed over all sorts of ground, and must also be able to use his weapons well on horseback. Hence there is nothing to be said against the practice of riding in the hunt, where there is suitable country with wild animals." ${ }^{5}$ Medieval writers followed Xenophon's suit, and, across Europe, hunting was undertaken as an exercise for the military elite that would contribute to military training. ${ }^{6}$ On the other hand, falconry, which was practiced by ladies as well as by knights, was an essentially courtly activity, practiced for display as well as for the pleasure it gave. The recreational aspect of riding is largely understated - pleasure from riding horses may have been part of the experience in hunting and pageants, but it was secondary to the main purpose of these activities, which were meant for display and for signalling one's belonging to a certain social class.

A rare instance of riding performed solely with the view of recreation, of distracting oneself, is found in the Middle English verse romance of Lanval. In this text, which is based on Marie de France's lay of Lanval, the protagonist, an impoverished knight Sir Lanval, rides out of the town in order to distract himself from sad thoughts about his predicament. Through practicing largesse, Lanval has lost all his fortune and had to leave the court. He was so poor that he was not invited to the dinner given by the mayor of the town. Instead, Lanval had to loan a harness, a saddle and bridle, to tack his horse. He rode out of the town, as the poet says "with little pride." It is remarkable that equestrianism in this case fulfils the purpose of recreation: an accident occurs that reflects Lanval's low social status at this point in the narrative and his dejection. His horse slips in the mud, and the hapless rider falls down, becoming the subject of humiliating taunts from the onlookers. Clearly, at this point in history, riding for its own sake was not an option - the pleasure it could give was inextricably connected to the awareness of riding being a social accomplishment, an exercise that was intended to demonstrate not only one's skill as a horseman but also one's status.

This impression that the pleasure of riding was not something to be enjoyed hedonistically and in solitude but was to be shown off to one's peers and potential patrons is strengthened when reading the first known manual of horsemanship written in medieval Europe: The Book of Horsemanship authored by Duarte I, King of Portugal, completed in the second half of the

\footnotetext{
${ }^{4}$ Ibid.

${ }^{5}$ Xenophon, Horsemanship, 48.

${ }^{6}$ See Duarte I of Portugal, The Book of Horsemanship by Duarte I of Portugal, trans. Jeffrey L. Forgeng (Woodbridge: Boydell Press, 2016), chapter 11 of part 5, 123-127. Also see Pietro Monte, Pietro Monte's Collectanea. The Arms, Armour and Fighting Techniques of a Fifteenth-Century Soldier, trans. Jeffrey L. Forgeng (Woodbridge: Boydell, 2018). For a discussion of the discourse on hunting big game as preparation for war in late medieval Portugal, see Ana Maria Rodriguez, "Hunting and Fighting on Horseback according to King João I and King Duarte of Portugal," in Horses Across the Medieval World, ed. Anastasija Ropa and Timothy Dawson (Leiden: Brill, forthcoming).
} 
fifteenth century. In his treatise, Duarte emphasizes the fact that riding is an inclusive exercise, which can be enjoyed by all people, irrespectively of their age, health and fitness:

Concerning the body, some people think they cannot be good riders because of weakness, old age, or obesity, and therefore lose the will and give up learning what they need in order to attain knowledge. They are manifestly wrong in this, and in many other good things that they lose because of this despair, when they could acquire them if they had good hope. Those who feel this way ought to dismiss this belief. They should reflect that they feel badly because they don't think they can acquire this art; but if it is due to weakness or age or some other thing, they could easily find others who are weaker and older but are quite good riders. Likewise with the other shortcomings: most people can recognize that, even if we have them, we can find others who have them to the same degree or greater, yet are not prevented from having considerable skill in riding. And when we see that people of equal or greater shortcomings acquire this art and practice it quite adequately, we should readily recognize that, if we have will and knowledge, the ability will not fail us, since people can do it who have less aptitude than ourselves. I truly think that if everyone believed this, few people would fail to become reasonably good riders for lack of physical aptitude. By "good" I do not mean "excellent," because I believe that in every country one finds very few people who have all the skills that the outstanding rider should have ... But it suffices that on horseback they should look and act like men, and not like animals less useful than the ones they ride. ${ }^{7}$

This is a very modern notion, and it is at the core of riding therapy and recreational riding as practiced today. Interestingly, later on, when discussing equestrian vaulting, Duarte mentions the example of his father, who, even at old age, could jump on the horse from the ground, beating younger riders: "having practiced this [vaulting over the saddle] when he was young, by the time he had passed seventy years, he could mount a horse of reasonable height from the ground without other aid more easily than most tall men on fifty." 8 Of course, Duarte's manual was intended for male warrior elite, so he automatically excluded women (though medieval noble and wealthy women could also be experienced riders) and non-noble people, who, even if they had to travel on horseback, would never be as skilful as Duarte's implied audience of knights.

After detailing the benefits of riding in chapters 2 and 3 of part I of the treatise, Duarte proceeds to chapter 4, entitled "The enjoyment that arises from this art," where he writes: "It stands to reason that those who excel in this art should have much enjoyment, given that we see people who excel in arts of little profit - such as throwing the bar, jumping with feet together, and other similar arts - enjoy praise for their excellence. If these people naturally rejoice in such praise, what should someone do who excels at the art of riding, which enjoys such a privileged place among the people to whom it pertains?" The enjoyment in question, however, is not only the pleasure one has in practicing a physical activity, but also that derived from displaying one's skill. Moreover, the joy derived from equestrian practice is also related to the awareness of its being useful - for Duarte, primarily useful on the battlefield, but also for impressing a potential patron. At the same time, Duarte does allude to the personal pleasure a rider receives from the exercise, if mounted on a good horse: "It is generally recognized that good and agreeable mounts

\footnotetext{
7 Duarte, The Book of Horsemanship, 54-55.

8 Ibidem, 136.

${ }^{9}$ Ibidem, 52.
} 
greatly please their riders' hearts, if they know reasonably well how to ride them."10 Again, good mounts were also a means of social display, as good horses were expensive and hard to maintain, so that possession of such a valuable equine reflected one's wealth and status.

\section{Riding for health, pleasure and show in the sixteenth and seventeenth centuries}

Overall, it is hard to distinguish between recreational riding, with the riders delighting in their horsemanship and the skills of their mounts, and the aspects of social display, with riding showing off their daredevil bravery and dominance over their steeds. Sixteenth-century riding treatises all suggest that riding skills are connected to masculinity, indeed, it being a mark of manliness. Men belonging to the elite (previously, the military elite, but, increasingly, representatives of the newly developing courtly culture ${ }^{11}$ ) were supposed to delight in their horsemanship, but was this delight genuine or part of one's public persona? We will probably never know for sure, and it is more likely than not that socially approved delight was an important aspect of public displays of horsemanship.

Between the late fifteenth and the early seventeenth centuries, a turn towards a more systematic approach to bodily culture seems to have been taking place, which is highlighted by the emergence of treatises on various physical activities and sports, most commonly fencing, but also horse riding, wrestling, horse vaulting, sports games, gymnastics and many others. Pietro Monte, who was active in the second half of the fifteenth and the first decade of the fifteenth century, left several treatises, two of which, The Appraisal of Men (De Dignoscendis Hominibus) (1492) and Collectanea - the first medieval encyclopedia of physical culture (Exercitiorum Atque Artis Militaris Collectanea) (1509), were devoted to the cultivation of arts and accomplishments that would make the ideal soldier. Naturally, physical education is important, and Monte highlights the importance of exercise - as well as diet, intellectual study and the cultivation of moral virtues - in maintaining a healthy lifestyle. Albeit Monte does not dwell on the technical aspects of horsemanship - apart from two relatively brief sections on vaulting included in the Collectanea - he does mention riding among the more important skills a perfect soldier should cultivate in Book 3, Chapter $10{ }^{12}$

Pietro Monte's treatise seems to have been quite popular in sixteenth-century Italy, having been disseminated in printed and manuscript formats, as well as having been translated from the original Latin..$^{13}$ Monte, who was probably a Spaniard, serving for most of his adult life in Italy, was but the first author who emphasized the importance of healthy lifestyle and exercise writing in early modern Europe. ${ }^{14}$ In sixteenth-century Spain, the decline of physical exercise

\footnotetext{
10 Ibidem.

11 On this process, see Treva J. Tucker, who explains that "At the beginning of the sixteenth century, members of the traditional French nobility tended to believe that the two qualities most necessary to a true nobleman were military service and virtue. To a nobleman of this period, military service specifically meant heavy cavalry service, which in the early sixteenth century still retained many of its medieval characteristics" ("Early Modern French Noble Identity and the Equestrian 'Airs Above the Ground'," in Global Interests: Renaissance Art between East and West, ed. Lisa Jardin and Jerry Brotton, 272-309 (London: Reaktion and Ithaca, 2000)).

${ }^{12}$ I discuss the programme of physical education outlined in the Collectanea in my paper "Pietro Monte's Collectanea: A Compendium of knowledge about the body, health and exercise," presented at the Physical Cultures of the Body conference, January 15, 2021 organized by the H. J. Lutcher Stark Center for Physical Education, the University of Texas, Austin.

13 For a discussion of theories about Monte's identity and biography, as well as the extant versions of the Collectanea, see the introduction to Jeffrey L. Forgeng, trans. Pietro Monte's Collectanea.

14 Thus, several treatises on horse vaulting alone have been published in different European countries in the seventeenth century: in Italy, Giocondo Baluda, Trattato del modo di volteggiare e saltare il cavallo di
} 
was important enough as to merit the notice of physicians, who recommended the "privileged classes - the nobles, clergy and wealthy middle class" to engage in regular exercise on order to lead a healthy life. ${ }^{15}$ Juan Carlos Altamirano highlights that "medical recommendations insisted that exercise should be carried out daily as a way of avoiding illnesses. Thus, the type of activity that had previously been considered work for nobles became a matter of exercise and health. The exercises doctors recommended included, amongst others, archery, walking up and down stairs, fencing and most important of all, horseback riding." 16 Altamirano comments on the change in the nature and purpose of physical activities advised - whereas previously they were part of the daily life of the military elite, they have evolved into fashionable pastimes, somewhat divorced from their practical application. Thus, he remarks that "the new situation of nobles at royal courts caused horseback riding to evolve from an activity mainly intended for combat into a distraction recommended by doctors. It became a way of keeping nobles occupied and in consequence a symbol of ostentation and power." 17 This development appears to have been common across Europe, with horse riding and other chivalric accomplishments and pastimes initially conceived as military training or as part of service due to the sovereign, including riding, fencing and hunting, becoming fashionable social accomplishments.

The aspects of pleasure and show involved in displays of horsemanship may be particularly closely interwoven in the case of young people, whose natural delight in fine mounts and their own skills is hardly distinguishable from their desire to impress the observers, both their peers and superiors. This appears to be the case in early modern Livonia, where, as Balthasar Russow, writing in the late sixteenth century, notes with disapproval, young representatives of the noble and gentle urban classes indulged in reckless displays of horsemanship:

Upon returning to the town, they all rode twice through the entire town and around the guildhall, where the bride, laden so heavily with gold, pearls, gilded jewelry and her high crown that she could barely stand on her feet, together with the other ladies were watching the riders from the high stairs of the guildhall. At last, both groups would divide and gallop over all the town streets, displaying their knightly prowess with leaping and racing. ${ }^{18}$

This tendency can be observed in the later centuries as well, when riding for the elite women and men became a social accomplishment as well as the source of delight. Horsemanship was becoming divorced from the practical necessities of travelling and participating in military campaigns.

legno (1630), in England, William Stokes, The Vaulting Master, or, The art of vaulting (London: I. Okes, 1641) and, in Germany, Johann Georg Paschen, Kurtze iedoch gründliche Beschreibung des Voltiger (Hall in Sachsen: Melchior Oelschlegen, 1666). One should also note Francis Willughby's Book of Games, which includes many athletics contests describes by Monte, for instance, that of throwing the bar and pole vaulting David Cram, Jeffrey L. Forgeng and Dorothy Johnston, Francis Willugbby's Book of Games: A SeventeenthCentury Treatise on Sports, Games, and Pastimes (Aldershot and Burlington VT: Ashgate, 2003)).

${ }^{15}$ Juan Carlos Altamirano, Historia y Origen del Caballo Espanol/History and Origins of the Spanish Horse (Malaga, 2005), 30.

16 Ibidem.

17 Altamirano, Historia y Origen del Caballo Espanol, 31.

${ }^{18}$ Balthasar Russow, Balthasar Rüssow's Livländlische chronik, ed. Eduard Pabst (F. I. Koppelson, 1845),

72. Translation mine. 


\section{Recreation and health as the objectives of riding among the elites of the eighteenth and nineteenth centuries}

In the early modern period, riding became gradually associated with leisure and health outcomes, though, in many cases, the status of riding as an elite pastime made it hard to distinguish between private and public motivations of riders. In the seventeenth century, riding was a skill men were supposed to show off, as illustrated by the words of Francis Osborne. In his "Advice to a Son" (1689), he explains: "next to Cloaths, a good Horse, becomes a Gentleman." ${ }^{19}$ Likewise, Jonathan Swift, a passionate rider himself, in a letter to Vanessa advises his friend the following treatment for her melancholy "I wish you would get yr self a Horse, and have always 2 Servants to attend you, and visit your Neighbors, the worse the better." ${ }^{20}$ It is worth noting that, at the time, riding was considered a necessary accomplishment for men, perhaps as a legacy of the assumption voiced by the sixteenthcentury Italian author Baldesar Castiglione, who famously insisted that a courtier should also be a skilful equestrian, saying that "I would have our Courtier a perfect horseman in every kind of seat." 21 Riding for ladies was considered primarily in terms of health and recreational benefits, although it gradually became more fashionable. By the nineteenth century, elegance in the saddle was expected from a lady who wanted to shine in the noble circles.

The contrast between the benefits that riding could bring for the representatives of both genders is perfectly illustrated by John Rarey, who, in the introduction to The Art of Taming Horses (1858) stated that

Every man and woman, girl and boy, who has the opportunity, should learn to ride on horseback. It is almost an additional sense - it is one of the healthiest exercises - it affords amusement when other amusements fail relaxation from the most severe toil, and in colonies or wild countries often the only means of travelling or trading. ${ }^{22}$

According to Rarey riding had health-enhancing and recreational benefits, as well as being a convenient means of travelling. Thus, he explains that

A great many persons in this country learn, or re-learn, to ride after they have reached manhood, either because they can then for the first time afford the dignity and luxury, or because the doctor prescribes horse exercise as the only remedy for weak digestion, disordered liver, trembling nerves - the result of over-work or over-feeding. Thus the lawyer, overwhelmed with briefs; the artist, maintaining his position as a Royal Academician; the philosopher, deep

\footnotetext{
${ }^{19}$ Francis Osborne, The Works of Francis Osborne, Esq; [... in Four Seeral Tracts, 9th ed. (London, 1689), par. 25.

20 Jonathan Swift, The Correspondence of Jonathan Swift, ed. David Woolley (Frankfurt am Main: Peter Lang, 2001), vol. 2, 424. On Swift's equestrianism, see Hermann Josef Real, "Swift Horsing Around: or, The Madness of Reason," in "....that I wished myself a horse' The Horse as Representative of Cultural Change in Systems of Thought," ed. Sonja Fielitz (Heidelberg: Winter, 2015). The gendered nature of the motivation of eighteenth- and nineteenth-century horsemanship, with women being advised to ride for exercise and men - for pleasure and social display, is discussed in Anastasija Ropa, "Gender in Horse Racing: Queens and Mistresses in the Sport of Kings," in Building Bodies: Gendered Sport and Transnational Movements. Yearbook of Women's History/Jaarboek voor vrouwengeschiedenis 38, ed. M. Derks, 87-102 (Hilversum: Verloren Publishers, 2019).

21 Baldesar Castiglione, The Book of the Courtier, trans. George Bull (London: Penguin Classics, 1976).

22 John S. Rarey, The Art of Taming Horses. A New Edition, revised, with important additions and illustrations, including chapters of riding and hunting, for the invalid and the timid (London: George Routledge \& Co., 1858), 110.
} 
in laborious historical researches; and the young alderman, exhausted by his first year's appreticeship to City feeding, come under the hands of the ridingmaster. $^{23}$

Further on, Rarey continues to elaborate on why women and men should practice riding, stating, aphoristically, and somewhat echoing Francis Osborne's words, that "A man feels twice a man on horseback." ${ }^{24}$ Rarey goes on to explain the positive social and business outcomes that a good equestrian can expect - a notion in line with Castiglione's implication that horsemanship could be a means of furthering one's career:

The student and the farmer meet, when mounted, the Cabinet Minister and the landlord on even terms - good horseman ship is a passport to acquaintances in all ranks of life, and to make acquaintances is one of the arts of civilised life; to ripen them into use or friendship is another art. On horseback you can call with less ceremony, and meet or leave a superior with less form than on foot. Rotten Row is the ride of idleness and pleasure, but there is a great deal of business done in sober walks and slow canters, commercial, political, and matrimonial. ${ }^{25}$

For women, however, the benefits of riding are of more private nature, as Rarey points out, "For a young lady not to be able to ride with a lover is a great loss; not to be able to ride with a young husband a serious privation." 26 It is noteworthy that Rarey not only does not mention health as a reason why a lady should take up riding: for him, ladies should ride in order to enjoy the company of men, rather than with the view of reaping health benefits or taking pleasure in the activity itself. This is in contrast with the reasons that may have motivated men to take up - or re-learn riding.

Meanwhile, other authors, Rarey's contemporaries, take a different view. In The Habit and the Horse (1857), the author lists many of the same benefits the fair readers/riders would reap from cultivating this exercise that Rarey mentions in relation to male riders: social assets, benefits for health that has been undermined by a sedentary lifestyle (nerves, indigestion, etc.) and diversion from the rigours of study. This is, perhaps, less surprising than may appear at first glance, because both the target audience and the author of The Habit and the Horse are female, whereas Rarey is a man addressing a male audience.

In the introduction to the treatise, J. Stirling Clarke provides the following justification of the benefits of the equestrian art for women: "Who that has observed some of the many fair equestrians of the present day, accompanied by their brothers or more favourite esquires, sweeping by in their morning canter, glowing with health and cheerfulness, but will readily admit that grace and beauty are never more finely displayed than in the practice and enjoyment of this invigorating exercise?" 27 At first glance, the authoress (for this is how she is described on the title page) alludes to the same context that Rarey mentions, that of enjoying riding in the company of men, although Mrs. Stirling Clarke stipulates the presence of brothers or squires, rather than men related by amorous ties with the fair rider. At the same time, the notions of pleasure and recreation, as well as health benefits are already outlined. In the following pages, Stirling Clarke elaborates on the recreational and health-promoting nature of riding, describing it as a "recreation which, out of an amusement, becomes the main spring

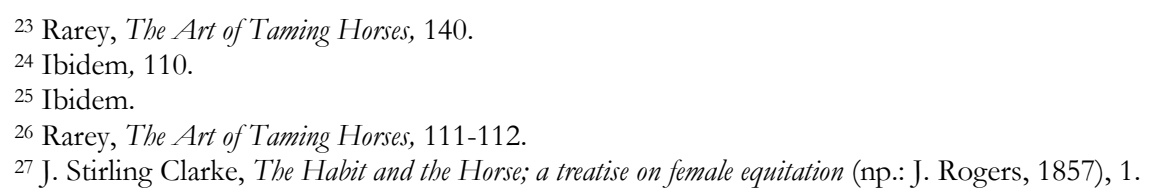


of health and joyousness to all its participants." 28 She recommends it to the parents, referring to medical opinions, and states that "Mothers need only consult their medical advisers upon this subject, to learn of the great benefits accruing from its early practice, especially in laying, as it surely does, the foundation of health for after life." ${ }^{29}$ Stirling Clarke explains the advantages of riding, which "of all the recreations with which this generation abounds over those which have preceded it, none creates more real and heartfelt enjoyment in the young, and indeed in all ages." 30 According to her, these encompass both physical and emotional benefits, making riding preferable to other pastimes, noting, in passing, its suitability for all ages, even though the treatise seems mostly intended for young riders. She further provides an example of "one lady friend approaching to, or even on the verge of three score years and ten, who attributes her excellent health to the use of this exercise from early youth, and whom, even now, can throw off her years in the enjoyment of the fine pure air of a morning country ride." 31 The reason is that "seated, as we are, high in air, surrounded by the pure atmosphere, and inhaling it, our elasticity is increased, and an indescribable sense of happiness pervades the whole frame." 32 Naïve as the reference to air surrounding the rider may sound, especially if riding in the midst of the city rather than in the countryside, anyone who has tried riding would concur that it does increase flexibility and gives satisfaction to the rider - the characteristics that lay the foundation of riding as therapy in the mid-twentieth Europe.

An earlier treatise, which was published in France some thirty years before Rarey's and Stirling Clarke's, Henri Le Noble's Traité d'équitation à l'usage des dames (1826), contains an entire section on the health benefits that riding could bring to female equestrians, referring to medical opinion on the subject. In the introduction to the treatise, Le Noble explains that he had avoided, where possible, the use of technical terms (possibly because he assumed his fair readers would not be interested in them or would find them incomprehensible), but "ai ajoute quelques notes qui contiennent les explications nécessaires, pour faciliter aux dames une étude aussi favorable à leur santé qu'à leur agrément" [has added some notes that contain the necessary explanations, in order to provide the ladies with a study that would be equally healthy and enjoyable]. ${ }^{33}$ In the note on medical benefits of equestrian exercise, Le Noble cites the opinion of several (unnamed) medical professionals, explaining first the benefits of exercise in general, then advocates the preference of equestrian exercise over other types of exercise, as the rhythmical movements of the horse enhance elasticity and promote the circulation of fluids through the body, in particular the circulation of blood. The author continues that, as a result, equestrian exercise is generally suitable for convalescents, hypochondriacs, melancholics and people of nervous disposition - all the conditions that are associated with noble women at the time. Unsurprisingly, it is concluded that equestrian exercise can bring more benefits to women than to men in enhancing their physical and psychological health: "Pour les dames surtout, cet exercice est encore beaucoup plus salutaire qu'aux hommes. Les maladies nerveuses, auxquelles ells sont si sujettes, ne peuvent souvent se guérir que par son secours" [This exercise is far more beneficial for ladies especially more than for men. The nervous diseases to which they are so susceptible often can be healed only though this intervention]. ${ }^{34}$ The note concludes that riding tones all bodily organs, with the

\footnotetext{
28 Stirling Clarke, The Habit and the Horse, 3-4.

29 Ibidem, 4.

30 Ibidem.

31 Stirling Clarke, The Habit and the Horse, 11.

32 Ibidem.

33 Henri Le Noble, Traité d'équitation à l'usage des dames (Paris: Ambroise Dupont, 1826), xxij.

34 Le Noble, Traité d'équitation à l'usage des dames, xxvij.
} 
most pronounced effect on the digestive and the circulatory systems, manifested in increased appetite (which is only to be expected after a ride in the country).

Denis Magner, the author of Magner's Classic Encyclopedia of the Horse (1887), likewise includes a section on equestrianism, which he begins by extolling the advantages of this exercise: "That there is no exercise to be compared with horseback-riding is conceded by all well-read physicians, as well as ladies and gentlemen who have given it a test. [...] It will prove a sure cure for dyspepsia in its worst form, if one will but persevere in the delightful recreation." 35 To those whom he imagines as objecting that "riding is too violent an exercise," Magner retorts that "The fundamental principle of the art of learning to ride is to learn one thing at a time, and learn to do that well, before attempting to do anything else." ${ }^{36}$ Having explained the basics of horse riding, Magner then details the benefits of equestrianism, stating: "If people would generally adopt horseback riding, they would starve out half our doctors, and would live in the enjoyment of much better health than they do now." 37 To prove his point, he cites "one of the many cases of restoration to health from this exercise," that of a young lady whom he has been instructing. They began with twenty-minutes walks in hand (the length of a short hippotherapy session today), after which Magner's pupil was "quite exhausted," and continued with lessons "three to four times a week for about four months." Magner recounts that "During this time she gained in strength to such an extent that at the expiration of the time she rode by car to Boston, a distance of twenty-five miles, did some shopping, thence to Cambridge to dine with her mother, and then returned home and rode ten miles on horseback," feeling as fresh at the end of the day as she did in the morning. ${ }^{38}$

Magner ends the section by quoting from the work of a New York medical professional Dr. Durant, "Horseback-Riding from a Medical Standpoint." It is worth reproducing the quote, remarkable not only for the elaborateness of its medical explanation, but also because it has much in common with the earlier opinions cited by Le Noble and the views of healthcare specialists today:

Horseback riding, as we have seen, is one of the most energetic modifiers of the circulation; it distributes the blood equally to every part of the capillary network, giving to each part its due proportion, by maintaining a due tension in every part by equalizing the temperature; it prevents equally anaemia and hyperaemia, and sanguineous stagnation, by the impulsion which it gives to the circulatory phenomena, and aids nutrition by the acceleration of the respiratory and digestive phenomena. It is by its effects upon the reactions of the blood to the nervous system that horse-back riding produces such a happy influence.

The effect of horseback-riding upon the functions of the system is especially remarkable upon that of digestion. It stimulates the appetite, excites and perfects digestion, favors absorption - in fact, to use a trivial expression, "It makes the bits go down." These are not the only results of the new energy imparted to the functions which we have studied, all of which concur in the accomplishment of this special one: it exercises a special influence upon the muscular fiber of the coats of the stomach and the intestines. $[\ldots]^{39}$

\footnotetext{
35 D. Magner, Magner's Classic Encyclopedia of the Horse (1887, repr. New York: Castle Books, 2004), 286.

36 Magner, Magner's Classic Encyclopedia of the Horse, 286.

37 Ibidem, 293.

38 Ibidem.

39 Magner, Magner's Classic Encyclopedia of the Horse, 294-295.
} 
Durant notes the effects of riding on the circulatory, digestive and respiratory systems, and, while specific disabilities for which hippotherapy is prescribed today are not mentioned by the nineteenth-century authors, the beneficial effects of hippotherapy for treating metabolic and circulatory disorders are recognized by therapists nowadays. ${ }^{40}$

As we can see, the benefits of riding were those characteristic of exercise in general, even though Le Noble (or his unnamed doctor(s)) emphasizes that riding is preferable to more active exercise in that it does not exhaust the practitioner: "Enfin à tous ces grands avantages, il faut joinder celui de procurer tout le bien que peut produire le mouvement, sans user les forces et fatigue le corps, comme le font tous les exercices actifs" [Finally, we must add to these great advantages the good effect that can be produced by movement performed without using the power and tiring the body, as do all active exercises]. ${ }^{41}$ Much the same is argued by Magner, who notes that equestrian exercise must be commenced gradually, in order to habituate the rider to it. In the first part of the twentieth century, it was recognized that riding as exercise promotes health and enhances physical and emotional well-being more generally, especially for the men and women living in the city, who had the means and leisure to afford keeping a horse or taking riding lessons. Colonel Thomas Hoyer Monstery, a famous nineteenth-century fencing and boxing instructor, recommended riding as one of the five sports (the four other being boxing, swimming, calisthenics and fencing) that promote overall bodily health and, in the words of Monstery's editor Ben Miller, "impart longevity toward the practitioner." 42

Similarly, in Black Beauty, the equine protagonist is acquired by just such a man, whom the doctor prescribed exercise on horseback, but who apparently was ignorant of horsemanship: "My new master was an unmarried man. He lived at Bath, and was much engaged in business. His doctor advised him to take horse exercise, and for this purpose he got me. [...] My master knew very little about horses, but he treated me well." 43 Black Beauty introduces what, at this point, is a typical situation: a bachelor who is very busy at work and neglects exercise experiences health issues and is advised riding in the country as health-promoting exercise. This type of rider does not belong to the countryside gentry, so he does not know much about horse care and is easily cheated by two successive grooms he employs, which leads him to sell Black Beauty. This episode signal the arrival of a new class of riders, men with means and leisure to take up riding for health, but with little knowledge about horses or riding. The emergence of this new class of riders is the precursor of riding therapy that was about to develop in the 1960s.

\section{The rise of riding therapy and other equine-assisted therapies in the mid- twentieth century}

In the eighteenth- and nineteenth-century riding manuals, the recreational and health outcomes of riding as exercise are hard to distinguish, and, indeed, both are presented as

\footnotetext{
40 See, for instance, Alexandra Rütten, Tiergestütz̧te Therapie, Für die Arbeit mit sprachentwicklungsgestörten Kindern (Saarbrücken: VDM Verlag Dr. Müller e.K. und Lizenzgeber, 2007).

${ }^{41}$ Le Noble, Traité d'équitation à l'usage des dames, xxviij. Le Noble states that the medical notes are taken out of the works of "nos meilleurs médecins, entre autres du Dictionnaire abrégé des Sciences Médicales" [our best doctors, among other the Short Dictionary of Medical Sciences] without proviging any further details.

42 Ben Miller, "Introduction," in Colonel Thomas Hoyer Monstery, Self-Defence for Gentlemen and Ladies. A Nineteenth-Century Treatise on Boing, Kicking, Grappling, and Fencing with the Cane and Quarterstaff, ed. Ben Miller (Berkeley: Blue Snake Books, 2015), 37.

43 Anna Sewell, Black Beauty (London: The Heirloom Library, 1949, repr. 1955), 171.
} 
complementary. After the world wars, which saw the gradual decline of the use of horses in the army and the rise of civilian riding for sport and recreation, a difference between the two goals of riding started to emerge. Today, the difference between therapeutic riding and riding therapy and leisure or recreational riding is formulated as follows: "In leisure riding, the riders' goal is primarily to improve riding skills and to have fun. In the case of therapy, enhancing physical, emotional and social well-being is central. Leisure riding and therapy goals often overlap." 44 As this definitions shows, the border between therapeutic and recreational riding remains fluid. It may be drawn artificially, by referring to a particular setting in which riding takes place (use of a certified yard or specially equipped area for riding therapy), the involvement of certain professionals (riding therapists, physical therapists, assistants), particular equipment, such as the therapeutic girth or adapted saddle, and, of course, the horse or another equine appropriate for the task. The exercises performed in the course of riding therapy may be adapted to target particular issues or disabilities, too. However, leisure riding also can bring therapeutic benefits, and one of the motivations for the rider can be exactly the improvements in physical, emotional and social health experienced as a result of riding.

The statistical data on the number of equestrians and riding therapy patients in Latvia are hard to obtain. Riding therapy is a recognized diagnostic and treatment method, with therapists registered as medical practitioners and working under the provisions of the Law on Medicine. However, the list of certified therapists and assistants is not publicly available. On the other hand, the number and details of equestrian clubs that are members of the Latvian Equestrian Federation can access on the Federation website. There are 90 such clubs, with a total number of 982 members, of whom nearly half (458) are under 22, hence competing in the junior division. ${ }^{45}$ Still, this includes only those clubs (and their individual riders), which decided to register in order, among other things, to participate in the official qualification competitions organised by the LEF. Not all riders and horse owners choose to register, as many of them do not compete at all, riding for recreation only, or compete only in training competitions, for which membership in the LEF is not required. Smaller riding yards, which offer riding therapy and leisure riding, but do not have a focus on sport, are less likely to request the LEF membership.

Another therapeutic dimension of horse-related leisure activity, as different from other recreational sports, is the involvement of the animal itself. Whereas a variety of animalassisted therapies have developed over the past decades, horse therapy or equine-assisted therapy is different from therapies involving other pets (cats and dogs). Pastorihno reports, "Horse owners claim a different type of relationship with their pet, which allows an active interaction and a different sort of companionship than the one present with small animal." 46

Research shows that riding therapy and equine-assisted therapy is beneficial to a wide variety of patients with physical, psychological and social limitations and promotes health and mobility in riders of all ages. Riding is one of the options that elderly citizens have discovered - or rediscovered - following an emphasis on equestrian sports as an activity for adolescents and young adults who aspire to competitive riding. Miriam Adelman and Kirilly Thomson note that

\footnotetext{
${ }^{44}$ Nataliya Berbyuk Lindström, Jens Allwood, Margareta Hâkanson and Anna Lundberg, "Multimodal Human-Horse Interaction in Therapy and Leisure Riding," in Proceedings of the 2nd European and the 5th Nordic Symposium on Multimodal Communication, ed. K. Jokinen and M. Vels, Linköping Electronic Conference Proceedings (Linköping: Linköping University Electronic Press, 2015), 64.

${ }^{45}$ Latvian Equestrian Federation, "LJF Biedri," www.leflatvia.lv/web/?id=400056 (accessed April 12, 2020).

${ }^{46}$ Ramiro M. Pastorihno, Pets as Sentinels, Forecasters and Promoters of Human Health (Cham: Springer, 2020), 280.
} 
Equestrian practices engage questions of generation in interesting ways [...] They can be unusually inclusive, in the sense that they encourage the participation of children and youth [...] and yet permit considerable continuity to committed equestrians and enthusiasts over the life course. [...] equestrian sports federations in several countries have programmes to ecnourage older people to take up (or come back to) riding. ${ }^{47}$

Although care must be taken in introducing or re-introducing the older riders to this activity, it can bring important health benefits, as "Horse riding has shown to be associated with improvement in balance and stability in elderly subjects from the community [...] horse riding was also associated with improvement in lower limb strength and whole body reaction in elderly subjects." 48 Associations and clubs for elderly riders are established in different parts of the world, and social media likewise has groups dedicated to elderly riders, such as the Facebook groups "Horse Riders over 50" and "women over 50 who love horses." 49

Whereas the benefits of riding as a health-promoting exercise have been known for centuries in different countries across Europe and beyond, it was in mid-twentieth-century Germany, as well as the UK and Scandinavian countries, that riding as therapy emerged as an alternative therapeutic method. ${ }^{50}$ Indeed, the German word for riding therapy, "Reittherapie," is used in many languages to signify therapeutic riding ("reitterapija" in Latvian and "рейттерапия" in Russian). In 1953, Dr. Max Reichenbach began using riding as therapy systematically in Germany, and he is credited as the founding father of modern therapeutic riding. It was nearly two decades later, in 1970, that the first association for riding therapy, Kuratorium für Therapeutisches Reiten, was established in Germany. Austria was quick to follow in the footsteps of its neighbour, and in 1977 Austria saw the meeting of its own professional organisation for riding therapy "Österreichisches Kuratorium für Hippotherapie." In 1985, another German-speaking country, Switzerland, saw the establishment of the association for therapeutic riding and vaulting "Schweizerische Vereinigung für Heilpädagogisches Reiten und Voltigieren” (SV-HPR). ${ }^{51}$

The Austrian council for therapeutic riding confirmed the existence of four types of therapeutic riding: hippotherapy, special therapeutic pedagogic riding and vaulting, integrative riding and ergotherapy using horses.

Hippotherapy is a branch of riding therapy that uses horse riding for therapeutic purposes: the patient sits on the back of a horse moving in walk. The movements of the horse are transferred to the femoral area and the spine of the patient, making the muscular-skeletal system of the patient adapt to the exercise. Thus, people who are paralyzed on one side of the body may develop a sense of balance in their body. Hippotherapy also has a positive influence on the muscle tone, stimulating weak muscles and relaxing the muscles that are tense, thus training correct posture, especially in the upper body, and improving the sense of balance. It targets a range of locomotory disorders, including the consequences of the stroke and brain injuries, paraplegia, spinal and femoral problems and can be used after the amputation of a limb, as well as for improving posture and alleviating muscular and metabolic

\footnotetext{
${ }^{47}$ Miriam Adelman and Kirilly Thompson (ed.), Equestrian Cultures in Global and Local Contexts (Cham: Springer, 2017), 7.

48 Pastorihno, Pets as Sentinels, 280.

49 "Horse Riders over 50," www.facebook.com/pg/HorseRidersOver50/posts/?ref=page_internal (accessed March 23, 2021) and "women over 50 who love horses," www.facebook.com/groups/ $165686520768509 /$ (accessed March 23, 2021).

50 Diana Düngen, Entwicklung der sozialen Kompetenz in der offenen Kinderarbeit, Begegnungen mit Tieren auf dem Ingenhammshof in Duisburg-Meiderich (Hamburg: LIT Verlag Dr. W. Hopf, 2007), 29.

51 Rütten, Tiergestütəte Therapie.
} 
disorders. The last point is interesting in that it reiterates the benefits of riding that were already noted, albeit in a slightly different form, by nineteenth-century medical professionals, including those cited by Le Noble and Denis Magner.

Therapeutic pedagogical riding and vaulting is different in that it promotes and enhances the existing abilities and resources of patients using a horse, involving psychological, psychotherapeutic and rehabilitation methods. This treatment helps people with disabilities to cope with their own difficulties by facilitating a sense of well-being, social behaviour and personal growth. It can be used with a range of disorders, such as dyslexia, concentration and perception problems, etc. Again, the psychological outcomes of riding were well-known to the riding instructors of the preceding centuries, having been stressed by Rarey, Stirling Clarke, Le Noble and Magner among others.

The goal of integrative riding, which is closely related to para-sports, is to provide the people with functional limitations with access to important forms of leisure, including sports and competitions. Specially made saddles, stirrups and bridles facilitate the participation of even severely disabled riders in equestrian activities, including dressage (para-dressage), which is adopted to the rider's impairment and abilities.

Riding for the disabled came into the limelight in 1952, when Liz Hartel, who had poliomyelitis, won the silver medal in dressage at the Olympic Games in Helsinki. Next year saw the establishment of Pony Riding for the Disabled Trust in the UK - an organization that provided disabled people with an opportunity to ride. Today, para-dressage is a highly competitive sport, where competitors are graded according to their disability. The Latvian paradressage rider Rihards Snikus (medical sport grade Ia), first started to ride in order to improve health and coordination under the guidance of a certified riding therapist Olga Shellere, who later became his paradressage instructor and saw Rihards win fourth place in the London Olympic Games in 2012 and the fifth place in the Rio Olympic Games in 2016.52 In an interview, he noted that riding gives him both a physical and psychological release. ${ }^{53}$

Ergotherapy using horses aims at achieving maximal independence in riders with physical, psychological and social disorders, who learn acting independently in horse-related context. Ergotherapeutic events can involve riding or taking care of horses and the environment and lead to improved cognitive skills, better coordination of motions and increased selfconfidence in performing daily activities. It is used as a means of improving motor, cognitive, psychological and emotional skills.

\section{Riding therapy and recreational riding in Latvia today}

\section{A. Riding therapy in Latvia}

Riding therapy has been offered in Latvia since the 1980s. The first projects in riding therapy were undertaken in 1984 in Kleisti equestrian centre, and Kleisti continues to offer the services of a certified riding therapist nowadays. Over ten years later, a riding therapy department was established at the rehabilitation centre in Vaivari. In 2000, riding therapy was officially recognized as a medical rehabilitation technology and included in all Latvian

\footnotetext{
52 The Latvian Paralympic Committee, "Rihards Snikus,” www.lpkomiteja.lv/sportists/rihards-snikus/ (accessed April 13, 2020). Rihards, who has cerebral palsy, is also the only DJ in Latvia with movement disorders.

53 Rob Howell, "Meet Dressage Rider and DJ Rihards Snikus" (June 21, 2019) www.paralympic.org/ news/meet-dressage-rider-and-dj-rihards-snikus accessed April 13, 2020).
} 
legislation regulating medicine. ${ }^{54}$ In 2014 , a handbook on riding therapy was issued, which contains basic definitions and guidelines for organizing riding therapy sessions. Dreimane defines riding therapy as follows:

Reitterapija ir ārstēšanas metode, kurā galvenais dziednieks ir zirgs. Tā ietver sevī problēmu risināšanu medicīniskā, psiholog̣iskā un sociālā rehabilitācijā. Faktori, kas nodrošina reitterapijas labvēlīgo ietekmi ir zirga ritmiskās un trīsdimensiju kustîbas, zirga ķermeņa siltums, terapeita, palīgu un pacienta sadarbība, kā arī ārstniecībai neierastā terapijas norises vieta. Zirgi jūt gan to, kā cilvēks šodien jūtas, gan to, kā cilvēks viņam pieskaras. Zirgi apbrīnojami labi izprot savas terapeita funkcijas un izjūt slimā cilvēka vajadzības.

Riding therapy is a treatment method where the main healer is the horse. It involves problem-solving in medical, psychological and social rehabilitation. The factors that ensure the positive impact of riding therapy are the rhythmical three-dimensional movements of the horse, the warmth of the horse's body, the collaboration between the therapist, the assistants and the patient as well as unusual environment for medical therapy. Horses feel both a person's condition on a certain day and the way a person touches it. Horses are wonderfully good at understanding their functions as therapists and sense the need of a patient.] ${ }^{55}$

A typical therapy session would involve "Nodarbībā piedalās zirgs, pacients, reitterapeits un 1 - 3 palīgi. Palīgu skaits mainās atkarībā no slimības veida un pacienta jāšanas prasmes" [a horse, a patient, a riding therapist and 1-3 assistants. The number of assistants would vary depending on the type of disease and the patients riding skills $].{ }^{56}$ Some patients can sit on horseback themselves and be lead around the school area or outdoors, with a therapist walking by the patient's side and observing the patient. In patients whose health or riding skills make it necessary, the therapist and/or the assistant(s) could walk close to the horse's flank and support the patient. The patients who cannot sit themselves would sit in front of a therapist or assistant, who also sits on horseback and supports the patient.

Riding therapy is provided at a variety of rehabilitation centres and yards across Latvia. Geographically, it is available in Mārupe, Vaivari (Vaivari rehabilitation centre), Kleisti (Kleisti equestrian centre), the Dagda parish, Jaunksemeri and Rüjiena (Rüjiena house for the elderly). Except for Rüjiena, most centres work with children and young people who need remedial treatment, rehabilitation or who are disabled. Rüjiena is the only place where all patients are the older citizens, who benefit not only from riding as therapy but also from equine-assisted therapy. ${ }^{57}$ Otherwise, equine-assisted therapy is less popular in Latvia, and it does not benefit from the same legal recognition as riding therapy. ${ }^{58}$

\footnotetext{
54 Natālija Dreimane, Reitterapijas rokasgrāmata (Riga: Jauno Jātnieku skola, 2014), www.sif.gov.lv/ nodevumi/nodevumi/5320/Reitterapijas_Rokasgramata_Natalija_Dreimane_JJS_2014.pdf (accessed March 22, 2021), 14.

55 Dreimane, Reitterapijas rokasgrämata, 15

56 Ibidem.

57 Rūjienas senioru māja [Rūjiena house for the elderly], "Reitterapija," http://rujienasseniorum aja.lv/reitterapija/ (accessed March 22, 2021).

58 One case of a medical professional offering the services of equine assisted therapy in Latvia is that of an existential psychologist, who has used the intervention of her private horse to work with a variety of patients, from hyper-active children to patients recovering from the stroke: Dace Kraveca, "Discovery of 'I-You' Relations in Communicating with the Horse. Or what do Martin Buber and horses have in common?” Existentia (2019): 13-21.
} 
To provide riding therapy services, the therapist has to be certified and have the certificate updated regularly (once in five years). Likewise, a riding therapy assistant needs to have an appropriate certificate. The horse and the place where the service is provided must be registered with the Latvian Professional Riding Therapy Association. Unfortunately, the Association does not maintain a publicly available register that would allow the public to access the list of certified riding therapists offering private practice. As a result, potential patients wishing to undertake the therapy with a certified practitioner are limited in their choice to the centres listed above.

A change in Latvian legislation, whereby riding therapy was included on the list of medical services for which the specialist providing the service (riding therapist) is to have earned a degree in medicine or physiotherapy, resulted in something of a crisis in the profession. The report compiled by the Youth Riders School indicates that, since the change in legislation was made in 2012, no educational institution has implemented the teaching of a riding therapy course. The School has also indicated that there is no single system for assessing and certifying horses suitable for riding therapy. Likewise, to date, there is no single official source that would summarize and present up-to-date information about the offer of riding therapy services, organizations providing the services and certified riding specialists. ${ }^{59}$ This report was submitted to the Ministry of Health in 2019, but so far the situation has not changed, which eventually may lead to a decrease in the number of certified riding specialists, because, in the absence of an officially recognized programme, no new specialists are entering the field, even though since February 15, 2019, the professions of riding therapist and assistant to riding therapist were reintroduced into the classificator of professions. ${ }^{60}$ Likewise, some of the specialists who received their certificates prior to 2012 decided to leave the field due to changes in personal or professional circumstances or failed to keep their certificates updated. This means that offer of riding therapy provided by certified specialists may continue to decrease unless the situation changes.

\section{B. Recreational riding in Latvia}

Recreational riding is relatively new in Latvia. During the Soviet period, the offer of recreational riding was limited to a few possibilities, such as at places of cultural importance, like national parks. Private ownership of horses for leisure was not common in the Soviet Union, and civilian riding was limited to equestrian activities with outcomes for sport. Horses were also used for agricultural works in rural areas until recently, and certain large breeding farms as well as some smaller yards still use horses for their daily labours (Fig. 1).

Many horse yards across Latvia offer both training and recreational riding options. The Latvian term for hacking out, as opposed to riding lessons, is "izjāde," which can be translated literally as "riding out," implying that this variety of riding takes place outside the school arena. Information about Latvian horse yards is available from the website HorseRiding.lv; the website also has partner branches for the two other Baltic countries, Lithuania and Estonia. It provides information about yards that offer livery, trainings and hacks, as well as the breeding farms, which can be accessed in the form of a list as well as by using an interactive map (Fig. 2). The amount and precision of information varies, because the data is provided and updated by the yards: this way, a certain yard may be offering recreational riding without

\footnotetext{
${ }^{59}$ Jauno Jātnieku skola, "Jauno Jātnieku skola iestājas par reitterapijas attīstību Latvijā," February 28, 2019, https://latvianhorses.lv/lv/news/jauno-jatnieku-skola-iestajas-par-reitterapijas-attistibu-latvija/ (accessed March 23, 2020).

60 "Profesiju klasifikators papildināts ar dažām profesijām un uzdevumu aprakstu," (February, 15, 2019), https://lvportals.lv/skaidrojumi/302040-profesiju-klasifikators-papildinats-ar-dazam-profesijam-unuzdevumu-aprakstu-2019 (accessed April 12, 2021).
} 
advertising its services on the website. Overall, however, this database offers a comprehensive overview of the offer of horse-related services in the country and its geographical distribution.

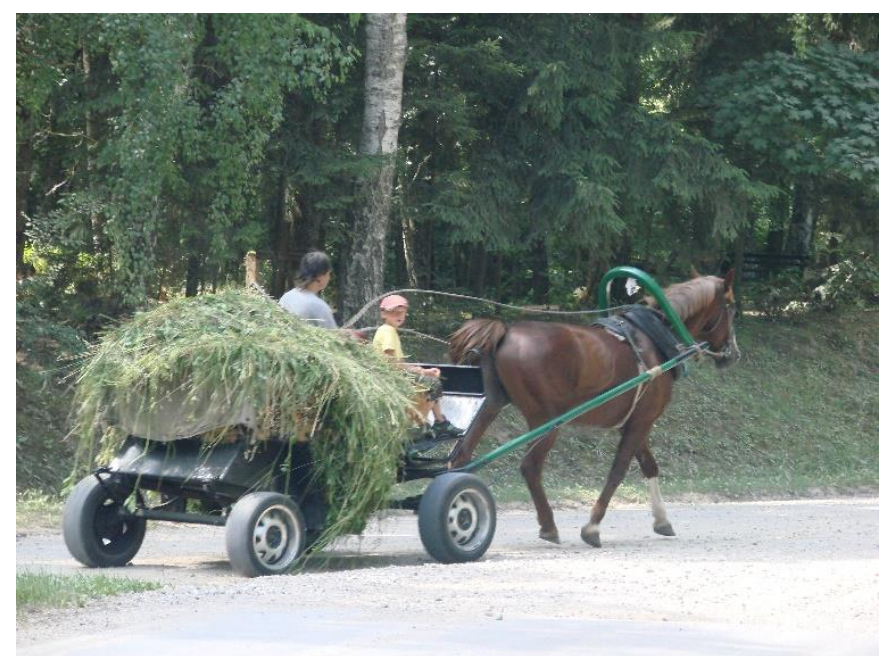

Fig. 5 The Latvian Warmblood of the heavy type working at the Tervete National Park. Photograph taken in 2010 by Anastasija Ropa.

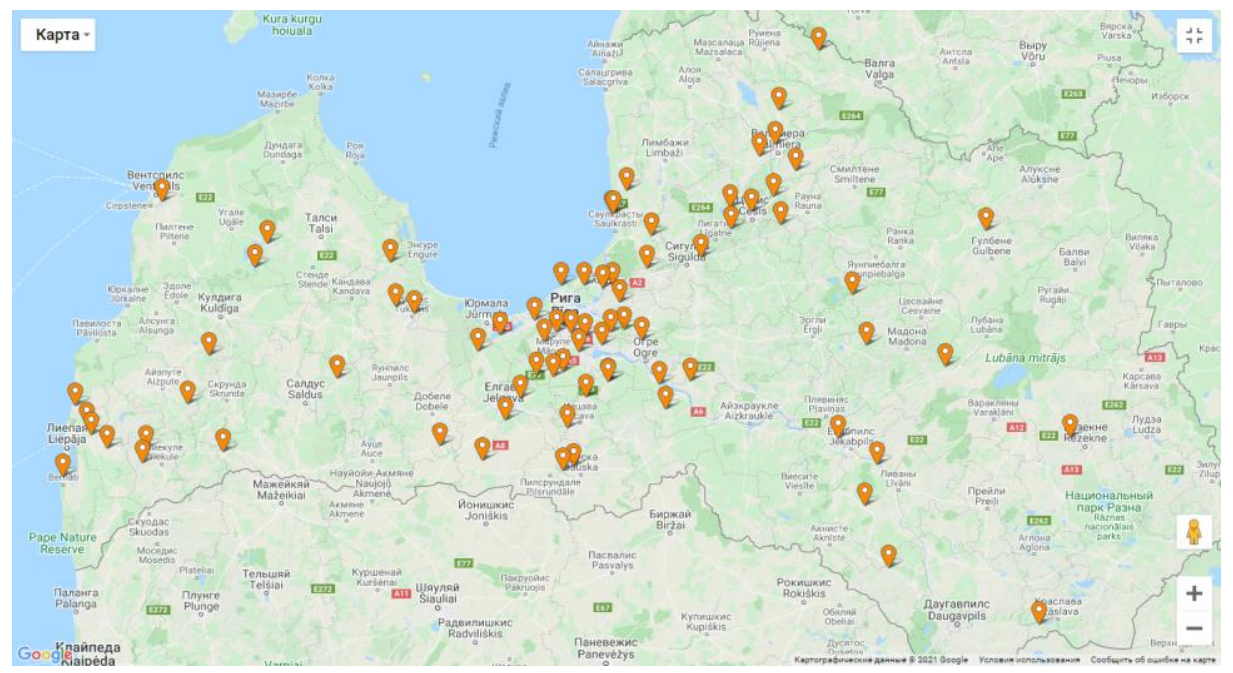

Fig. 6 Interactive map of riding yards that offer hacks. Source: http://horseriding.lv/lv/map/type/izjades. Accessed March 20, 2021

Looking at the map, we can see a large conglomeration of yards offering hacks centring around the capital of Latvia, Riga. This concentration coincides with the distribution of population and capital, as Riga and its vicinity account for the greater proportion of the Latvian population than the other regions. Thus, at the beginning of 2021, the population of Riga was 627,487 , and further 374,466 residents lived in the vicinity of the capital, whereas the other regions had a lower population, with 255,968 residents in Latgale region, 237,407 
in Kurzeme region, 228,409 in Zemgale region and only 183,938 in Vidzeme region. ${ }^{61}$ It is therefore unsurprising that the suburban area of Riga and its satellite towns are developing into a veritable "horse country," with new private yards being established and offering livery services for horse owners as well as leisure riding and other services, such as skijoring in winter, outings in horse carriage or, in winter, in a sleigh, photo sessions with horses, etc. These yards often position themselves as family-friendly, offering picnic areas, a tour of the stables, opportunities to feed treats to horses before or after a ride, to groom and take care of the horses, etc. (Figs 3 and 4).

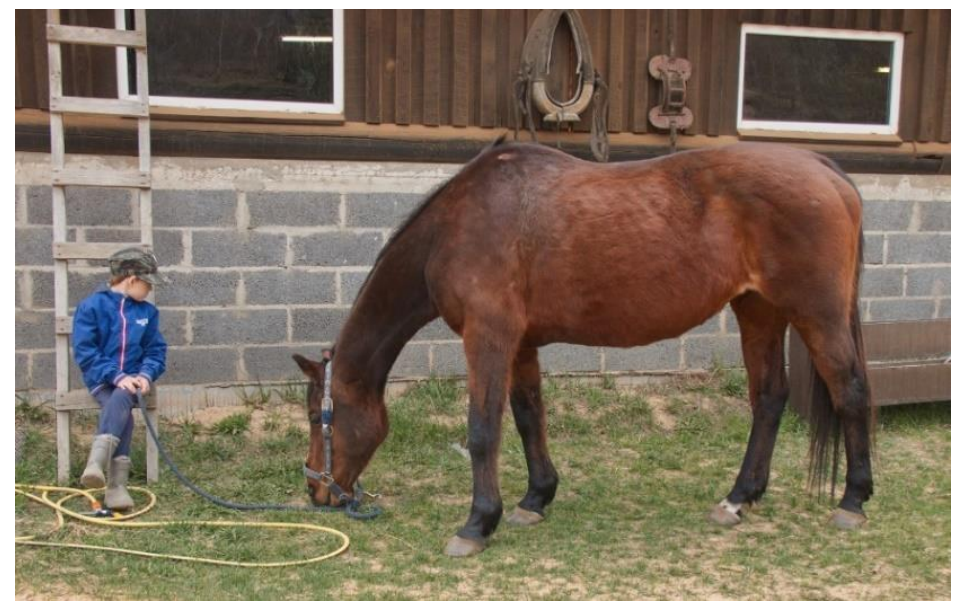

Fig. 7 Enjoying an opportunity to take care of a horse by taking it out to graze in springtime in Baldone, Latvia.

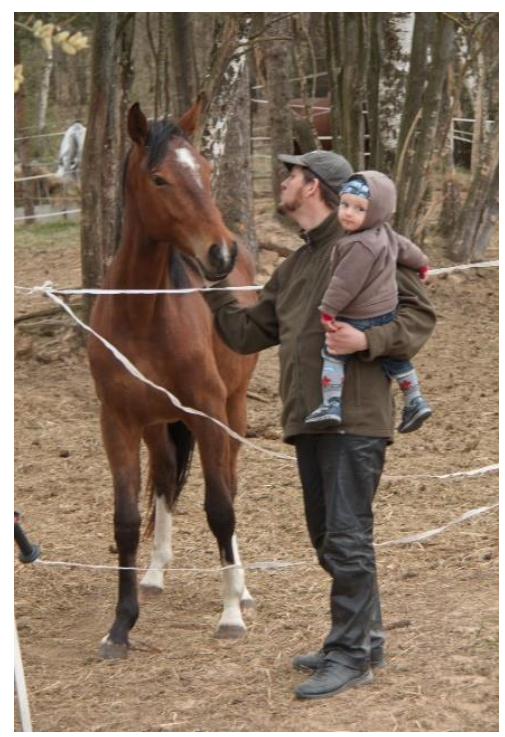

Fig. 8 Socializing with a young Latvian Warmblood, photograph taken in Baldone, Latvia.

${ }^{61}$ Central Statistical Bureau of Latvia, "ISG020. Population number and its change by statistical region," http://data1.csb.gov.lv/sq/43247 (accessed March 25, 2021). 


\section{Common breeds used for riding therapy and recreational riding in Latvia}

The most common breed of horses in Latvia is the Latvian Warmblood (LW). It has two types: the light type (often commonly known as the "sport" type) and the heavy type (also known as the "old" or "harness" type). Other native breeds are the Latvian Ardennes (an endangered coldblood breed of horses that is peculiar to Latvia) and the Latvian trotter (a critically endangered warmblood breed, again, only found in Latvia). ${ }^{62}$ There are other horse and pony breeds in Latvia, including German breeds (TR, HN, HL), the English Thoroughbred and the Arabian, but these are rarer and less likely to be offered for hacks, although Latvian Warmbloods, especially those of the light type, often have a high percentage of blood from these breeds. ${ }^{63}$

Each horse breed has physical and intellectual characteristics that make it more or less suitable for hacking, or for specific kinds of hacking. Physical characteristics include conformation, size, endurance and speed, and intellectual ones are docility (obedience to the rider), calmness and intelligence. While individual horses are all different, each breed has typical physical standards, but also certain intellectual characteristics associated with it. While physical characteristics are easy to evaluate, intellectual ones are less easy to perceive, and certain breeds are subject to stereotypes: thus, Arabians and Thoroughbreds are seen as nervous but intelligent, while Latvian Warmbloods of the heavy types are often described as being dull. These stereotypes are misleading, but they influence the way people, including clients who may have little or no knowledge about horses, may view the horses they are offered to ride and hence their experience while hacking.

The smaller riding yards situated in places of natural beauties or in the vicinity of heritage sites, such as near Gaizinkalns ("Betini"), the Daugava bank ("Agates"), around Cesis and Sigulda, in Ligatne and in the National Park of Tervete usually provide hacks with Latvian Warmbloods of the heavy type. This is a good choice of a horse hacking out: first of all, the Latvian Warmblood of the heavy type corresponds well with the notions of national cultural heritage and Latvian countryside, being the historical horse type used for agricultural activities since at least the nineteenth century. Second, the physical and intellectual qualities associated with this breed type make it, as a whole, particularly suitable for recreational riding in the countryside. This type is characterized by stocky conformation, typically smaller height as compared to the light type, endurance and hardiness.

Latvian Warmbloods are good doers, meaning they need less fodder of lower quality as compared to sport horses. They are a very versatile breed, which is successfully used in hobby level equestrian sports, including show-jumping and dressage, as well as equestrian vaulting, and are driven in harness, which, historically, has been one of their main functions. In recent years, they have been the primary choice of riding therapy horses in Latvia, due to their lower height and natural docility. ${ }^{64}$ Also, many Latvian Warmbloods have level gaits, especially the trot, which is easy to sit to - an important consideration for an inexperienced or occasional rider.

\footnotetext{
${ }^{62}$ For an overview of breeds, see Laine Orbidane, "Preservation of Historical Horse Breeds in Latvia," paper presented at the LASE International Scientific Conference "Historical Practices in Horsemanship and Equestrian Sports," August 27, 2020, Riga, Latvia.

${ }^{63}$ See, for instance, the history of Latvian Warmbloods published on the website of the Association of the Latvian Warmblood Breeders, "History," http://lszaa.lv/latvijas-zirgu-skirne/vesture/ (accessed April 26, 2021) and the Latvian Equestrian Federation, "History of Horse Breeding," http:/ /www.leflatvia.lv/web/?id=400050 (accessed April 26, 2021).

${ }^{64}$ Dreimane, Reitterapijas rokasgrämata, 14.
} 


\section{Legal and ethical framework for equestrian training and recreational riding}

In Latvia, different regulations are applicable to equestrian training for sport and to recreational riding, which includes hacks, skijoring, being driven in carriage or sleigh, etc. In training for equestrian sports, the most popular of them in Latvia being the Olympic disciplines of show-jumping and dressage as well as the non-Olympic discipline of harness driving, the instruction can be carried out only by a certified specialist, same as in other sports. The trainer must hold a certificate of $\mathrm{A}, \mathrm{B}$ or $\mathrm{C}$ category in order to provide riding lessons, lessons in equestrian vaulting or harness driving. The certification is carried out by the council of the Latvian Sport Federation according to part three of article 20 of the Sport Law, with the procedure and requirements that a sport specialist should meet in order to gain the right to work in the sport industry being determined by Regulations Nr. 77 of 26 January 2010 issued by the Cabinet of Ministers, "Regulations on the procedure for the certification of sport specialists and requirements set for sport specialists." ${ }^{65}$ In turn, riding therapy can be offered only by a certified therapist, and the centre and horse are also subject to certification. By contrast, the services related to equestrian recreation do not necessitate specialist education or training from the provider. Hacking out can be offered by any yard and any horse owner, which raises certain concerns about health and safety of both riders and horses.

This is in contrast with the situation in many other countries in Europe: for instance, in the UK, riding schools that offer instruction for children and adults are part of the British Association of Riding Schools (BARS): membership in this associations entails regular annual checks of the riding school. These checks are carried out by an inspector coming to the school and inspecting the horses, tack (equipment used for riding), the personnel, including the stable hands involved in the operation of the yard, as well as the premises. While horse-related accidents both during trainings and in competition can happen anywhere, regular checks ensure the provision of at least minimal standards. They ensure that the horses are in good health, not lame and well-fed, at least at the time of the inspection, and that there is suitable equipment on the premises, as well as the fact that the premises themselves are safe.

In Latvia, information about riding clubs that are members of the Latvian Equestrian Federation can be found on its website (www.ljf.lv). Still, only those yards that want their riders to be able to enter the competitions approved by the LEF need to obtain the status of clubs and to provide the necessary information. Those yards that only offer hacks and other services without the aim of training riders for sport do not apply for this status, which requires additional paperwork and the annual payment of fees. Still, the Code of Ethics issued by the LEF specifies that its regulations are to be observed by "any person in contact with the horse in both sport and daily life." 66 The Code is divided into a section the basic principles, on responsibility towards the horse and on responsibility towards equestrian sport and other people. At its very beginning, article 1.1, the code specifies that "The basis of behaviour for any person in contact with the horse shall be respect towards the right of the animal for wellbeing irrespectively of its type of use," which would involve horses working in leisure and recreational industries. Likewise, article 1.5 states that "The place where a person performs his professional activities shall have appropriate conditions and technical equipment. A person must not work in the conditions that may compromise his professionalism or the horse's well-being." These two examples show that the LEF code envisages not only sport

\footnotetext{
${ }^{65}$ Regulations of the cabinet of Ministers Nr.77, "Noteikumi par sporta speciālistu sertifikācijas kārtỉbu un sporta speciālistam noteiktajām prasībām" [Regulations on the procedure for certifying sport specialists and requirements set for sport specialists] https://likumi.lv/doc.php?id=204329 (accessed April 26, 2021).

${ }^{66}$ Ethical Code of the Latvian Equestrian Federation, http://www.leflatvia.lv/web/?id=418218 (accessed April 26, 2021). Translations are the author's own.
} 
professionals but all workers in the equestrian sector, so that this code would seem to be applicable to specialists involved in recreational riding, too.

The code places at its forefront animal welfare values, though certain provisions, such as article 2.4 ("Any person that is in contact with the horse must ensure the use of appropriate and suitable equipment"), are aimed at ensuring the safety and welfare of both the animal and the human handler. In this case, of course. the duty for providing equipment would lie with horse owners and workers involved in providing riding services rather than the clients, who may have little or no knowledge of the equipment that would be safe, appropriate and fitting for a horse - even though broken equipment can be recognized for such even by inexperienced people.

Likewise, article 3.1 determines that "It is important for any person who is in contact with the horse to develop continuously and to improve his skills of horse training and care as well as to increase his level of his theoretical and practical veterinary care. The person is responsible for raising the level of his professional competence, theoretical and practical knowledge and participates as much as possible in the development of horse welfare and training standards." Hence, all workers involved with horses, irrespectively of their professional status as trainers, owners, stable hands, etc. and of whether the horses in question are used for sport or other activities, such as therapy or recreation and leisure, have the duty of developing themselves in order to ensure equine welfare. The indirect outcome of this development would be the improvement of the clients' experience, as a healthy and welltrained horse is a pleasure to ride, whereas a sick horse or a horse with a low level of training is not only less pleasant to ride but also dangerous.

\section{Conclusion. Horses as pets, companions or health and recreation labour force?}

The recreational and health-enhancing benefits of riding have been known for centuries: the authors who wrote about riding as early as the fifteenth century, such as Dom Duarte, noted the delight of a rider in mounting a horse. The Renaissance riding masters likewise noticed both the social benefits of riding - the likelihood of being noticed and promoted by a noble patron - and the enjoyment a good equestrian would experience from the manege riding. In the eighteenth and nineteenth centuries, when riding lost its connection with chivalry, the social aspects of riding as an elite pastime came to the fore, with men and women cultivating riding as a profitable and healthy pastime, from which they likewise received social benefits. At the time, riding remained not only an elite pastime but also the most expedient and universal means of transport: to visit one's neighbours in the countryside, one had to ride, but it was also a means of showing off one's wealth, good breeding, education and health. Thus, riding as a public spectacle and riding as healthy recreation were inextricably linked.

In the late nineteenth and early twentieth centuries, there emerged a class of people who could afford riding but who had not learned it in their youth, either because they had no need to ride back then, or did not have the means to do so, or both. These people, many of them young businessmen like the character in Black Beauty, or the ladies who grew up in urban areas, had no knowledge of horses, but recognized the social benefits that presenting oneself on horseback held. The riding exercise also seems to have become a fashionable exercise prescribed by physicians, possibly because of its aristocratic associations, but also it was perceived as less strenuous than more active physical exercise (certainly riding in walk creates the impression of being easier than actually walking). It is only in the mid-twentieth century that various modalities of riding therapy emerged, primarily in Germanophone countries, from which they spread all over the world. At the same time, leisure riding gradually lost its associations with sports and the army, becoming, in many countries, an affordable outdoor pastime, much like skiing, kayaking, etc. Still, the aristocratic connotations of riding as an 
expensive hobby remain, influencing the reasons a certain group of people decide to take it up as recreation or at least to try it out. As in the past, the aspects of show and enjoyment remain interwoven in the motivation of equestrians, even though nowadays the emphasis is placed, at least apparently, on the health-enhancing outcomes of riding as a nature sport that fosters the relation with natural surroundings on the one hand and the horse as the partner on the other hand.

Restrictions on travelling outside the country, together with restrictions on indoor recreational services and trainings lead to a surge of interest in leisure riding, as well as other outdoor recreational activities, such as hiking and skiing, among the residents of Latvia. Coupled with a ban on amateur, training and youth competitions, it resulted in a shift of emphasis from training for competition to non-competitive riding in order to enhance one's skills, facilitate the contact with the equine partner and enjoy the environment in which riding takes place - all of which are components of leisure riding. It remains to be seen if this new shift towards horse riding as an inclusive family activity and the emphasis on its noncompetitive, recreational and health-enhancing effect is a lasting one.

\section{References}

\section{Primary Sources}

Castiglione, Baldesar. The Book of the Courtier. Trans. George Bull. London: Penguin Classics, 1976.

Duarte I of Portugal. The Book of Horsemanship by Duarte I of Portugal. Trans. Jeffrey L. Forgen. Woodbridge: Boydell Press, 2016.

Le Noble, Henri. Traité d'équitation à l'usage des dames. Paris: Ambroise Dupont, 1826.

Magner, D. Magner's Classic Encyclopedia of the Horse. 1887, repr. New York: Castle Books, 2004.

Monstery, Thomas Hoyer. Self-Defence for Gentlemen and Ladies. A Nineteenth-Century Treatise on Boing, Kicking, Grappling, and Fencing with the Cane and Quarterstaff. Ed. Ben Miller. Berkeley: Blue Snake Books, 2015.

Monte, Pietro. Pietro Monte's Collectanea. The Arms, Armour and Fighting Techniques of a FifteenthCentury Soldier, trans. Jeffrey L. Forgeng. Woodbridge: Boydell, 2018.

Osborne, Francis. The Works of Francis Osborne, Esq; [...] in Four Seeral Tracts. 9th ed. London, 1689.

Rarey, John S. The Art of Taming Horses. A New Edition, revised, with important additions and illustrations, including chapters of riding and hunting, for the invalid and the timid. London: George Routledge \& Co., 1858.

Russow, Balthasar. Balthasar Rüssow's Livländlische chronic. Ed. Eduard Pabst. F. I. Koppelson, 1845.

Sewell, Anna. Black Beauty. London: The Heirloom Library, 1949, repr. 1955.

Stirling Clarke, J. The Habit and the Horse; a treatise on female equitation. Np.: J. Rogers, 1857.

Swift, Jonathan. The Correspondence of Jonathan Swift. Ed. David Woolley. Frankfurt am Main: Peter Lang, 2001.

Xenophon. Horsemanship. Trans. Morris H. Morgan. Boston: Little, Brown, and Company, 1893.

\section{Secondary sources}

Adelman, Miriam and Kirilly Thompson (ed.). Equestrian Cultures in Global and Local Contexts. Cham: Springer, 2017.

Altamirano, Juan Carlos. Historia y Origen del Caballo Espanol/History and Origins of the Spanish Horse. Malaga, 2005. 
Berbyuk Lindström, Nataliya, Jens Allwood, Margareta Hâkanson and Anna Lundberg. "Multimodal Human-Horse Interaction in Therapy and Leisure Riding." In Proceedings of the 2nd European and the 5th Nordic Symposium on Multimodal Communication. Ed. K. Jokinen and M. Vels, Linköping Electronic Conference Proceedings, 61-71. Linköping: Linköping University Electronic Press, 2015.

Central Statistical Bureau of Latvia. "ISG020. Population number and its change by statistical region." http://data1.csb.gov.lv/sq/43247. Accessed March 25, 2021.

Dreimane, Natālija. Reitterapijas rokasgrāmata. Riga: Jauno Jātnieku skola, 2014. www.sif.gov.lv/nodevumi/nodevumi/5320/Reitterapijas_Rokasgramata_Natalija_Drei mane_JJS_2014.pdf. Accessed March 22, 2021.

Düngen, Diana. Entwicklung der sozialen Kompetenz in der offenen Kinderarbeit, Begegnungen mit Tieren auf dem Ingenhammshof in Duisburg-Meiderich. Hamburg: LIT Verlag Dr. W. Hopf, 2007.

Jauno Jātnieku skola. "Jauno Jātnieku skola iestājas par reitterapijas attīstību Latvijā." February 28, 2019. https://latvianhorses.lv/lv/news/jauno-jatnieku-skola-iestajas-parreitterapijas-attistibu-latvija/. Accessed March 23, 2020.

Kraveca, Dace. "Discovery of 'I-You' Relations in Communicating with the Horse. Or what do Martin Buber and horses have in common?" Existentia (2019): 13-21.

Orbidane, Laine. "Preservation of Historical Horse Breeds in Latvia." Paper presented at the LASE International Scientific Conference "Historical Practices in Horsemanship and Equestrian Sports,” August 27, 2020, Riga, Latvia.

Pastorihno, Ramiro M. Pets as Sentinels, Forecasters and Promoters of Human Health. Cham: Springer, 2020.

Real, Hermann Josef. "Swift Horsing Around: or, The Madness of Reason.” In “....that I wished myself a horse' The Horse as Representative of Cultural Change in Systems of Thought." Ed. Sonja Fielitz. Heidelberg: Winter, 2015.

Rodriguez, Ana Maria. "Hunting and Fighting on Horseback according to King João I and King Duarte of Portugal." In Horses Across the Medieval World. Ed. Anastasija Ropa and Timothy Dawson. Leiden: Brill, forthcoming.

Ropa, Anastasija. "Pietro Monte's Collectanea: A Compendium of knowledge about the body, health and exercise." Paper presented at the Physical Cultures of the Body conference, January 15, 2021 organized by the H. J. Lutcher Stark Center for Physical Education, the University of Texas, Austin.

—. "Gender in Horse Racing: Queens and Mistresses in the Sport of Kings." In Building Bodies: Gendered Sport and Transnational Movements. Yearbook of Women's History/Jaarboek voor vrounengeschiedenis 38. Ed. M. Derks, 87-102. Hilversum: Verloren Publishers, 2019.

Rütten, Alexandra. Tiergestützte Therapie, Für die Arbeit mit sprachentwicklungsgestörten Kindern. Saarbrücken: VDM Verlag Dr. Müller e.K. und Lizenzgeber, 2007.

Tucker, Treva J. "Early Modern French Noble Identity and the Equestrian 'Airs Above the Ground'." In Global Interests: Renaissance Art between East and West. Ed. Lisa Jardin and Jerry Brotton, 272-309. London: Reaktion and Ithaca, 2000. 